\title{
PENGARUH METODE SIRKUIT TRAINING TERHADAP HASIL SPRINT 60 METER SMP NEGERI 21 TERPADU PONTIANAK
}

\author{
Budiman, Edi Purnomo, Andika Triansyah \\ Program Studi Pendidikan Jasmani FKIP Untan Pontianak \\ Email: budiman.dhi10@gmail.com`
}

\begin{abstract}
This study aims to see the effect of the training circuit method on the results of the 60 meter sprint at SMP Negeri 21 Terpadu Pontianak. The method used in this study is a free experiment involving two variables of the training circuit method using the 60 meter sprint method. The sample of students and female students who took part in the extracurricular training at SMP Negeri 21 Terpadu Pontianak sports 60 meter running number consisting of 20 students. The research technique used tests and measurements. The results of this study indicate the effect of circuit training on the results of the 60 meter sprint on extracurricular students at SMP Negeri 21 Terpadu Pontianak. This can be proven based on the calculation results, where the ttest value is 5.869> the $t$ table value (1.729), so the alternative hypothesis ( $\mathrm{Ha}$ ) is accepted and the null hypothesis $(\mathrm{Ho})$ is rejected. This shows that the Circuit Training method has an influence on the results of the 60 meter sprint at SMP Negeri 21 Terpadu Pontianak.
\end{abstract}

Keywords: Circuit Training, Sprint 60 Meter, SMP Negeri 21 Terpadu Pontianak

\section{PENDAHULUAN}

Pendidikan Jasmani merupakan suatu mata pelajaran yang menjadi wadah pengembangan peserta didik dalam kegiatan berolahraga di sekolah. Dimana pendidikan jasmani itu sendiri memberikan kesempatan kepada peserta didik untuk mengembangkan pengetahuan dan keterampilan yang berkaitan dengan aktifitas jasmani, perkembangan estetika, dan perkembangan sosial. Menurut Adang Suherman (2009:1), menyatakan "Pendidikan jasmani, olahraga dan kesehatan yang diajarkan disekolah memiliki peranan sangat penting, yaitu memberikan kesempatan kepada peserta didik untuk terlibat langsung dalam berbagai pengalaman belajar melalui aktivitas jasmani, olahraga dan kesehatan yang terpilih yang dilakukan secara sistematis.

Pendidikan Jasmani merupakan suatu mata pelajaran yang menjadi wadah pengembangan peserta didik dalam kegiatan berolahraga di sekolah. Dimana pendidikan jasmani itu sendiri memberikan kesempatan kepada peserta didik untuk mengembangkan pengetahuan dan keterampilan yang berkaitan dengan aktifitas jasmani, perkembangan estetika, dan perkembangan sosial. Menurut Adang Suherman (2009:1), menyatakan "Pendidikan jasmani, olahraga dan kesehatan yang diajarkan disekolah memiliki peranan sangat penting, yaitu memberikan kesempatan kepada peserta didik untuk terlibat langsung dalam berbagai pengalaman belajar melalui aktivitas jasmani, olahraga dan kesehatan yang terpilih yang dilakukan secara sistematis".

Melalui pendidikan jasmani diharapkan siswa dapat memperoleh berbagai pengalaman untuk mengungkapkan kesan pribadi yang menyenangkan, kreatif, inovatif, terampil meningkatkan dan memelihara kebugaran jasmani. Pendidikan jasmani di sekolah terbagi dalam beberapa cabang yaitu bola besar, bola kecil, dan atletik.

Tujuan dari pendidikan bertujuan untuk mengembangkan sikap jujur, sportif, disiplin, tanggung jawab, kerja sama, percaya diri. Pembelajaran olahraga seringkali mengalami kendala seperti kurangnya sarana dan prasarana, keterbatasan guru dalam membuat model pembelajaran yang inovatif.

Atletik merupakan cabang olahraga yang wajib diajarkan pada peserta didik menengah pertama, olahraga atletik sangat penting, karena atletik merupakan induk dari semua cabang olahraga hampir semua cabang olahraga mengandung gerakan dasar atletik. Nomor-nomor yang ada dalam olahraga atletik meliputi jalan, lari, lompat, dan lempar.kategori olahraga lari di bagi menjadi beberapa macam, seperti lari jarak pendek/sprint, lari jarak menengah dan lari jarak jauh. Pada penelitian ini 
penulis berkenan mengambil penelitian tentang lari jarak pendek sprint.

Seorang atlet sprint yang dikatakan baik itu sangat memerlukan penguasaan teknik dasar yang baik. Atlet sprint yang memiliki teknik dasar yang baik pasti akan memberikan performa yang baik pula. Ada tiga teknik jarak pendek yaitu teknik start, teknik lari, dan teknik memasuki garis finish. Lari jarak pendek tujuannya adalah melakukan kecepatan secara horizontal dengan dan dorongan badan kedepan. Ada beberapa tahapan lari jarak pendek yaitu tahap reaksi dan dorongan,tahap percepatan, tahap transisi, tahap kecepatan maksimum, pemeliharaan kecepatan, dan finish (Eddy Purnomo dan Dapan, 2013: 34). Teknik start dan teknik gerakan lari merupakan aspek yang sangat penting karena menjadi dasar dalam lari cepat atau sprint.

Saat lari cepat juga diimbangi dengan ayunan tangan yang maksimal dan seimbang, sehingga dapat membantu untuk meningkatkan kecepatan lari. Selain itu langkah kaki dan paha lebih diangkat sampai rata-rata air, sehingga akan tercipta langkah lari yang lebih baik. Usaha untuk meningkatkan teknik dasar lari jarak pendek harus memperhatikan prinsip-prinsip latihan, agar keterampilan gerak bisa tercapai secara optimal sangat perlu dilakukan pengetahuan kondisi latihan yang baik melalui pemberian intruksi yang tepat.

Tujuan metode latihan atau training adalah untuk membantu atlet meningkatkan keterampilan dan prestasi yang akan di raih atlet semaksimal mungkin. Program sirkuit training yaitu latihan yang cara latihannya seorang atlet bisa melewati beberapa pos atau beberapa stasiun yang harus diselesaikan dalam waktu yang telah ditentukan. Latihan merupakan sebuah proses dalam meningkatkan suatu kemampuan yang dimiliki seseorang, latihan juga dikenal dengan istilah training. Dengan latihan yang baik maka hasil yang diperoleh akan baik pula. Latihan adalah upaya meningkatkan kualitas fungsional organ-organ tubuh serta psikis pelakunya. Oleh sebab itu, latihan yang dilakukan harus disusun dan dilakukan secara tepat dan benar sesuai dengan tujuan yang ingin dicapai. Latihan dengan cara tidak tepat akan mempengaruhi perkembangan anak, baik secara fisiologi atau psiologis. (Tandiyo Rahayu, 2009: 15).

Menurut Soekarman (1987:70) latihan cirkuit adalah suatu program latihan yang dikombinasikan dari beberapa item-item latihan yang tujuannya dalam melakukan suatu latihan tidak akan membosankan dan lebih efisien. Latihan cirkuit akan tercakup latihan untuk kekuatan otot, ketahanan otot, kelentukan, kelincahan, keseimbangan, dan ketahanan jantung paru. Latihan-latihan harus merupakan siklus sehingga tidak membosankan. Latihan cirkuit biasanya satu cirkuit ada 5 sampai 15 stasiun, berlangsung selama 10-20 menit. Istirahat dari stasiun ke lainnya 15-20 detik. Namun untuk tingkatan siswa penulis memiliki inisiatif untuk mengadakan latihan lari 50 meter dengan dua circuit atau dua pos. Satu cirkuit atau satu pos nya ada lima stasiun. Latihan sirkuit training ini bukan berarti hanya diberikan dalam waktu latihan yang pendek saja, akan tetapi bisa juga diberikan pada awal-awal dimusim latihan, atau dimusim latihan selanjutnya sebagai variasi untuk menghilangkan kebosanan latihan.

Keunggulan berlatih dengan model latihan sirkuit training di antaranya adalah : (1) Circuit training mampu meningkatkan kelincahan dan daya ledak otot. Seperti yang sudah dijelaskan sebelumnya, bahwa circuit training merupakan latihan fisik yang memiliki beberapa pos yang didalamnya ada gerakan lompat dan juga berlari; (2) Circuit training mampu meningkatkan stamina dan daya tahan. Daya tahan adalah suatu faktor fisik yang sangat penting dalam menentukan performa seorang atlet. Jika daya tahannya kuat, maka para atlet akan mampu memberikan performa yang baik saat mengikuti kejuaraan. Daya tahan tubuh yang baik ditandai dengan kemampuan tubuh dalam mensuplai kebutuhan oksigen; (3) Circuit training mampu meningkatkan kekuatan otot. Selain mampu meningkatkan kelincahan dan daya tahan, circuit training juga akan berpengaruh pada kekuatan otot tubuh. Dengan program sirkuit training yang dilakukan selama 3 kali seminggu dan Lari cepat atau sprint merupakan semua perlombaan lari dimana peserta berlari dengan kecepatan maksimal sepanjang jarak yang ditempuh. Pada dasarnya gerakan lari untuk semua jenis sama. Namun dengan demikian dengan adanya perbedaan jarak tempuh, maka sekalipun sangat kecil terdapat pula beberapa perbedaan jarak tempuh, maka sekalipun sangat kecil terdapat pula beberapa perbedaan dalam pelaksanaannya. Sedangkan yang dimaksud dengan perbedaan atau pembagian jarak dalam nomor lari adalah lari jarak pendek (50400), lari menengah (800-1500 meter), lari jarak jauh (5000 meter atau lebih). Dengan demikian, lari jarak pendek atau sprint mempunyai jenis lari dari start sampai finish yang dilakukan dengan kecepatan maksimal. selama 40 menit persesi latihan akan mampu meningkatkan kekuatan otot tubuh.

Lari cepat atau sprint merupakan semua perlombaan lari dimana peserta berlari dengan kecepatan maksimal sepanjang jarak yang ditempuh. Pada dasarnya gerakan lari 
untuk semua jenis sama. Namun dengan demikian dengan adanya perbedaan jarak tempuh, maka sekalipun sangat kecil terdapat pula beberapa perbedaan jarak tempuh, maka sekalipun sangat kecil terdapat pula beberapa perbedaan dalam pelaksanaannya. Sedangkan yang dimaksud dengan perbedaan atau pembagian jarak dalam nomor lari adalah lari jarak pendek (50-400), lari menengah (8001500 meter), lari jarak jauh (5000 meter atau lebih). Dengan demikian, lari jarak pendek atau sprint mempunyai jenis lari dari start sampai finish yang dilakukan dengan kecepatan maksimal.

Lari sprint merupakan olahraga dasar yang dapat dilakukan oleh semua orang, baik dari usia anak-anak, remaja, dewasa, hingga lansia. Saat ini olahraga lari sudah berkembang menjadi lebih baik di kalangan masyarakat luas khususnya masyarakat Kalimantan Barat. Banyak kompetisi perlombaan lari yang sering diselenggarakan Pemerintah Provinsi Kalimantan Barat bahkan berbagai pihak dengan bantuan berbagai sponsor baik antar pelajar, tingkat kabupaten/kota, tingkat provinsi, nasional bahkan internasional. semangat masyarakat untuk olahraga lari sangat tinggi. hal tersebut terbukti dengan banyaknya terbentuk klub-klub para penggemar aktifitas lari untuk semua kalangan.

Berdasarkan hal tersebut, terlihat jelas bahwa olahraga lari sudah banyak diminati oleh masyarakat, karena olahraga sudah menjadi gaya dan kebutuhan bagi mereka. Olahraga lari sudah menjadi suatu hal yang mudah masyarakat lakukan tanpa beban karena tidak memerlukan peralatan khusus yang sulit didapatkan oleh masyarakat. Lari sprint merupakan lari dengan kecepatan penuh sepanjang jarak yang harus ditempuh. Disebut dengan lari cepat karena jarak yang ditempuh adalah pendek atau dekat. Jadi, dalam nomor lari ini diutamakan adalah kecepatan yang maksimal mulai dari awal lari (start) sampai akhir lari (finish). Mengingat dalam lari ini yang diutamakan adalah kecepatan maka kekuatan fisik yang prima sangat diperlukan.

Berdasarkan analisis terhadap kondisi yang dialami di SMP Negeri 21 Terpadu Pontianak maka penelitian mencoba menerapkan program latihan sirkuit training untuk mengatasi beberapa kendala yang dialami atlet. Menurut Kardjono (2008:65) sirkuit training adalah suatu sistem latihan yang dapat memperbaiki secara serempak fitnes keseluruhan dari tubuh, yaitu unsur-unsur power, daya tahan, kekuatan, kelincahan, kecepatan, dan lain-lain komponen fisik. Karena itu bentuk-bentuk latihan dalam latihan sirkuit biasanya merupakan kombinasi dari semua unsur fisik. Misalnya lempar bola, naik turun tangga, lari bolak balik, berbagai bentuk latihan beban, sit-up, full-up, lompat-lompat dan sebagainya. Untuk dapat melatih atau berlatih secara efisien adalah melalui latihan sirkuit. Karena dalam latihan sirkuit ini kan tercakup unsur-unsur yang terlatih seperti kekuatan otot, ketahanan otot, kelentukan, kelincahan, keseimbangan dan katahanan jantungparu (Titi Juliantine, Yuyun Yudiana, dan Herman Subarjah, 2007).

SMP Negeri 21 Terpadu Pontianak jalan Tanjung Raya II Kecamatan Pontianak Timur Kota Pontianak. SMP Negeri 21 Terpadu Pontianak adalah salah satu sekolah yang memiliki ekstrakurikuler atletik. Ekstrakurikuler ini menampung siswa-siswi yang memiliki minat dan bakat dibidang olahraga khususnya atletik. Saat ini para atlet atletik di SMP Negeri 21 Terpadu Pontianak sedang semangat-semangatnya dalam mengukir prestasi. Hal ini tersebut terbukti dengan hasil prestasi yang di raih saat kejuaraan antar pelajar se-kabupaten/kota di tahun 2019. Prestasi ini tidak ada kemungkinan bisa di pertahankan di kejuaraan-kejuaraan yang akan datang kalau tidak ada latihan terus menerus. karena yang perlu diperhatikan dalam olahraga atletik adalah kemampuan fisik, teknik, dan psikis. Hal tersebut harus ditingkatkan secara seimbang agar mendapatkan hasil yang maksimal saat kejuaraan. Pada saat peneliti mengikuti berbagai informasi mengenai perkembangan atlet sprint atletik SMP Negeri 21 Terpadu Pontianak dan menyaksikan para atlet lari sprint, terlihat bahwa peserta ekstrakurikuler atletik SMP Negeri 21 Terpadu Pontianak khususnya atlet lari sprint memiliki fisik yang cukup baik. Teknik dasar lari sprint mereka juga cukup baik, namun atlet belum bisa memaksimalkan kemampuan dengan baik. Sebagian besar mengalami kesalahan pada teknik dasar gerakan lari pada langkah lari sprint. teknik yang mereka pelajari saat latihan, tidak diterapkan seluruhnya saat pengetestsan atau pengambilan waktu. Sehingga mengurangi performa saat pengambilan dan hasil nya dicapai pun kurang maksimal. 
Berdasarkan berbagai uraian diatas, peneliti bermaksud mengadakan eksperimen untuk mengetahui pengaruh latihan cirkuit training untuk mengatasi permasalahan yang ada pada atlet atletik nomor lari sprint eksrakurikuler SMP Negeri 21 Terpadu Pontianak berjumlah 20 atlet, sehingga dapat mengetahui pengaruh latihan sirkiut training. Dari latar belakang tersebut peneliti mengadakan penelitian dengan judul "Pengaruh latihan sirkuit training terhadap prestasi lari 60 meter di SMP Negeri 21 Terpadu Pontianak".

\section{METODE PENELITIAN}

Metode penelitian adalah suatu cara yang harus di tempuh peneliti untuk mencapai suatu tujuan yang harus diinginkan. Tujuan dari penelitian adalah untuk mengetahui permasalahan yang ada di lapangan dengan cara yang sesuia dengan prosedur penelitiannya. Metode penelitian yang digunakan dalam penelitian adalah metode eksperimen. Desain yang dipergunakan peneliti dalam penelitian ini adalah One-Group-PretestPosttest Design yaitu desain yang mengunakan satu kelompok satu kelompok yang terlebih dahulu diberikan test atau pretest awal untuk mengukur sejauh mana kemampuan siswa dalam melakukan gerak dasar lari jarak pendek (O1), Selanjutnya diberikan suatu latihan atau perlakuan yang dapat meningkatkan kualitas gerak dasar lari jarak pendek (X) dan kemudian dilakukan kembali atau yang terdiri atas obyek atau subyek yang mempunyai kualitas dan karakteristik tertentu yang ditetapkan oleh peneliti untuk dipelajari dan kemudian ditarik kesimpulannya. Sedangkan populasi dibatasi sebagai sejumlah penduduk atau individu yang paling sedikit mempunyai satu sifat yang sama (Sutrisno Hadi, 2004: 182). Sedangkan menurut Burhan Nurgiyantoro, dkk (2000: 20-21) populasi adalah seluruh anggota subjek penelitian yang memiliki kesamaan karakteristik.

Berdasarkan pendapat tersebut maka di simpulkan bahwa populasi adalah keseluruhan subjek atau objek yang menjadi sumber penelitian untuk diukur, dipelajari, dianalisa dan ditarik kesimpulannya. Populasi penelitian ini mengambil waktu kecepaan lari seluruh peserta atlet lari jarak pendek bisa disebut lari sprint yang mengikuti ektrakurikuler atletik lari jarak pendek di SMP N 21 Terpadu Pontianak yang berjumlah 20 peserta yang berusia 13-15 tahun.

Menurut Suharsimi Arikunto (2006:131) sampel adalah apabila seseorang ingin menelii semua elemen yang ada dalam wilayah penelitian maka penelitiannya merupakan penelitian populasi. Sekedar ancer-ancer, apabila subyeknya kurang dari
100 orang, lebih baik diambil semua sehingga penelitiannya merupakan penelitian populasi.

Metode pengambilan sampel yang digunakan adalah sampling jenuh yaitu teknik penentuan sampel dengan pertimbangan tertentu. Menurut (Sugiyono, 2016: 124-125) "teknik sampling jenuh adalah teknik penentuan sampel bila semua anggota populasi digunakan sebagai sampel. Hal ini sering dilakukan bila jumlah populasi relatif kecil, kurang dari 30 orang, atau penelitian yang ingin membuat ge neralisasi dengan kesalahan yang sangat kecil. Istilah lain sampel jenuh adalah sensus, dimana semua anggota populasi dijadikan sampel. Jadi sampel dalam penelitian ini adalah seluruh peserta didik yang mengikuti ektrakurikuler atletik lari jarak pendek atau sprint di SMP N 21 Terpadu Pontianak yang berjumlah 20 peserta yang berusia 13-15 tahun.

Dalam penelitian ini teknik pengumpulan data menggunakan observasi dengan test pengukuran. Berdasarakan metode serta pendekatan penelitian yang menggunakan model one-group pretestposstest design, maka test pengukuran dilakukan.

Teknik pengumpulan data dalam penelitian ini dilakukan tes dan pengukuran. Proses pengumpulan data diawali dengan memberikan penjelasan pelaksanaan tes dan melakukan pemanasan metode, hal ini menggambarkan kemampuan dasar peserta didik.

Tahap perlakuan (treatment) Bertujuan untuk meningkatkan kemampuan atlet dari hasil tes awal. Pelakuan yang diberikan kepada atlet ekstrakurikuler lari jarak pendek SMP Negeri 21 Terpadu Pontianak berupa metode circuit training. Dimana peserta didik melakukan gerakan yang telah disusun sesuai dalam teori circuit training dan disesuiakan dengan tujuan latihan.

Tes akhir (post-test) Tes akhir merupakan tahap akhir dari penelitian untuk mendapatkan data atlet untuk sebagai acuan dari hasil peningkatan yang ada dari keberhasilan program latihan yang diberikan.

Alat pengumpulan data biasanya dikenal dalam penelitian dengan istilah instrumen penelitian. Instrumen penelitian adalah alat yang digunakan penelitian untuk memperoleh sebuah informasi. Agar data yang kita dapatkan berkualias dan relevan kia memerlukan instrumen yang harus sesuai dengan tujuan dari penelitian.

Analisis data merupakan kegiatan setelah data dari seluruh responden atau sumber data lain terkumpul. Kegiatan dalam analisis data adalah mengelompokkan data berdasarkan variabel dan jenis variabel, metabulasi data berdasarkan variabel dari seluruh responden, menyajikan data tiaovariabel yang diteliti, melakukan perhitungan untuk menjawab rumusan masalah, dan melakukan perhitungan untuk 
menguji hipotesis yang telah diajukan. (Sugiyono, 2011:207). Uji normalitas dilakukan untuk mengetahui sampel yang diteliti normal atau tidak. Ada beberapa cara yang dapat dilakukan dalam analisis data yaitu dengan cara kolmogorof-smimov, liliefors, chi kuadrat dan sebagainya (Yulingga Nanda Hanief dan Wasis Himawanto, 2017: 68). Pada penelitian ini peneliti menggunakan uji liliefors yang akan digunakan untuk mengetahui normalitas dari sampel yang ingin diteliti.

Pengujian kesamaan varians dari variasi latihan terhadap kecepatan lari sprint 60 meter. Dalam melakukan uji homogenitas varian terbesar dibandingkan varian terkecil (Uji F) digunakan rumus sebagai berikut :

Keterangan :

$$
F=\frac{\text { Varians Terbesar }}{\text { Varians Terkecil }}
$$

Varians (Kuadrat dari simpangan baku)

Setelah data berdistribusi normal dan memiliki varians yang homogen maka data yang terkumpul dari pre-test dan post-test di analisis secara statistik dengan menggunakan rumus uji $\mathrm{T}$ untuk mengetahui besarnya pengaruh variabel bebas terhadap variabel terikat setelah dibanding dengan taraf signifikasin $0,05 \%$, yaitu :

$$
t=\frac{M d}{\sqrt{\frac{\sum x^{2} d}{n(n-1}}}
$$

Keterangan

t : tabel

Md : rata-rata selisih antara pre-test dan post-test

$\Sigma \mathrm{X}^{2} \quad$ : jumlah kuadrat antara selisih pre-test dan post-test

$\mathrm{N}$ : jumlah sampel

\section{HASIL DAN PEMBAHASAN}

HASIL

Penelitian ini dilaksanakan di SMP Negeri 21 Terpadu Pontianak saat pelaksanaan penelitian ini dilaksanakan pada hari rabu tanggal 15 januari 2020. Dalam penelitian ini dilakukan dua kali pengambilan data, pengambilan data pertama yang disebut pretest dilaksanakan untuk mengetahui

kemampuan awal siswa yang mengikuti

Instrumen penelitian yang digunakan dalam penelitian ini adalah SMP Negeri 21 Terpadu Pontianak. Data kemampuan lari sprint 60 meter penelitian ini adalah variabel dalam penelitian. Hasil waktu berupa detik ekstrakulikuler atletik nomor lari sprint 60 meter sebelum diberikan perlakuan metode latihan circuit training, setelah melaksanakan perlakuan 9 pos dengan metode latihan circuit training, setelah itu peneliti mengambil data kedua yaitu posttest atau test akhir untuk mengetahui apakah terdapat peningkatan kemampuan lari sprint 60 meter.

yang telah diperoleh waktu terendah 7,62 sedangkan waktu tertinggi 11,90. Adapun distribusi frekuensi data tentang kemampuan awal dan akhir lari sprint 60 meter dapat disajikan dalam tabel berikut ini:

Tabel 1. Distribusi Frekuensi Data Kemampuan Awal dan Akhir lari sprint 60 meter

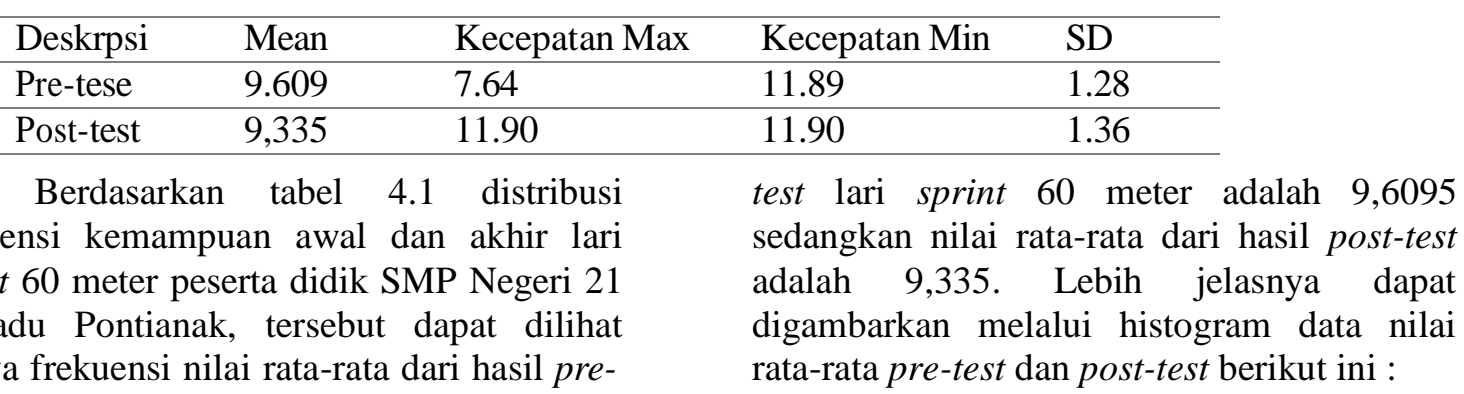
rata-rata pre-test dan post-test berikut ini :

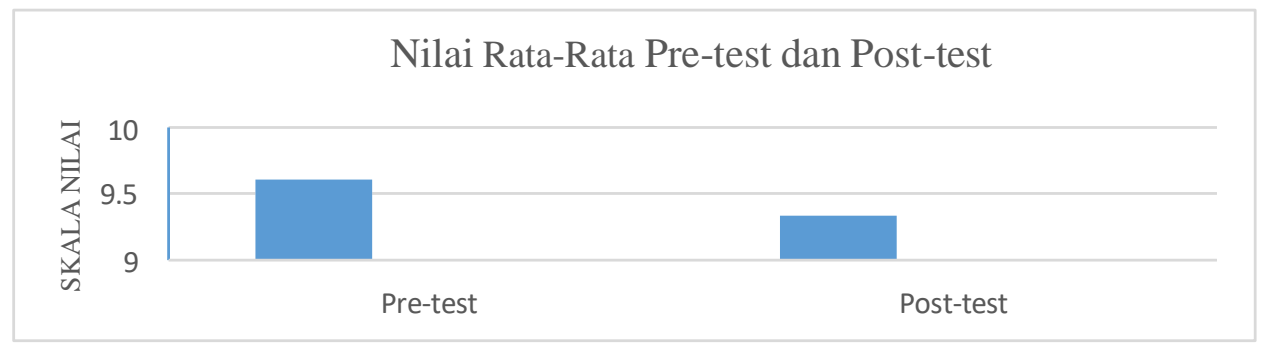

Gambar 1. Nilai Rata-Rata Pre-Test Dan Post 
Suatu penelitian biasanya seorang peneliti memberikan atau tidak memberikan suatu hipotesis untuk menarik sebuah kesimpulan. Pengujian hipotesis sangat diperlukan dengan tujuan untuk menguji kebenaran sebuah teori atas suatu pengetahuan dalam artian hubungan sebab akibat, yang disajikan melalui pengolahan data hasil penelitian.

Setelah seluruh data penelitian didapatkan atau telah dihasilkan, maka tahap selanjutnya adalah menganalisa data. Hasil penelitian ini, penganalisaan data dilakukan secara manual dengan menggunakan bantuan sebuah alat yaitu kalkulator dan program Microsoft Excel 2013. Hal ini dilakukan dengan tujuan untuk mendapatkan tingkat

Berdasarkan hasil penelitian penghitungan melalui pengaplikasikan rumus penghitungan dan hasil yang lebih akurat dan mudah untuk di pahami.

Hasil perhitungan bahwa nilai ratarata peningkatan tes akhir dibandingkan dengan tes awal adalah 0,2745 sehingga dapat diambil kesimpulan terdapat peningkatan sebesar 5,869\% hasil lari sprint 60 meter pada siswa SMP Negeri 21 Terpadu Pontianak setelah diberikan sebuah perlakuan latihan sirkuit training.

Berdasarkan hasil tersebut, dapat disimpulkan bahwa nilai $t_{\text {test }}\left(\mathbf{5 , 8 6 9 )}>t_{\text {tabel }}\right.$ (1,729), sehingga hipotesis alternatif dalam penelitian ini diterima. Hal ini berarti bahwa ada pengaruh latihan circuit training terhadap hasil lari sprint 60 meter pada peserta didik ekstrakulikuler SMP Negeri 21 Terpadu Pontianank.

uji-t akhirnya didapatkan sebuah data, sebagaimana tabel 2 berikut:

Tabel 2. Rata-Rata Pretest-Postest

\begin{tabular}{|c|c|c|c|c|c|}
\hline Uraian & Rata-rata & $\mathbf{t}_{\text {test }}$ & d.b & $\mathbf{T}_{\text {tabel 5\% }}$ & Keterangan \\
\hline Pretest & 9,609 & 5,869 & 19 & 1,729 & $\begin{array}{l}\text { Terdapat } \\
\text { Pengaruh }\end{array}$ \\
\hline Posttest & 9,335 & & & & \\
\hline
\end{tabular}

\section{Pembahasan}

Penelitian ini dilakukan dengan menganalisis uji pengaruh antara tes awal dan tes akhir untuk mengetahui uji peningkatan kemampuan peserta didik dalam melakukan lari sprint 60 meter. Proses pertama yang dilakukan peneliti yaitu melakukan pretest terhadap peserta didik yang mengikuti ekstrakulikuler atletik lari sprint setelah itu dilanjutkan dengan melakukan perlakuan menggunakan latihan circuit training. Setelah peserta didik melakukan perlakuan yang telah diberikan, penelitian melakukan tes kedua yaitu posttest kepada siswa untuk mengetahui perubahan atau peningkatan kemampuan siswa dalam melakukan lari sprint 60 meter.

Dari hasil uji perbedaan yang dilakukan terhadap hasil tes awal dan tes akhir hasil lari sprint 60 meter pada siswa SMP Negeri 21 Terpadu Pontianak, diperoleh nilai $t_{\text {test }}$ sebesar 5,869. Sedangkan $t_{\text {tabel }}=1,729$. Ternyata thitung yang diperoleh lebih besar dari pada $t_{\text {tabel}}$, yang berarti hipotesis nol ditolak Dengan demikian dapat disimpulkan bahwa setelah diberikan perlakuan selama 6 kali pertemuan, terdapat perbedaan yang signifikan antara hasil tes akhir dengan tes awal pada hasil lari sprint 60 meter pada siswa ekstrakulikuler SMP Negeri 21 Terpadu Pontianak, bahwa nilai rata-rata peningkatan tes akhir dibandingkan dengan tes awal adalah 0,2745 sehingga dapat diambil kesimpulan terdapat peningkatan sebesar $2,86 \%$ hasil lari sprint 60 meter pada siswa ekstrakulikuler SMP Negeri 21 Terpadu Pontianak.

Berdasarkan hipotesis penelitian yang menyatakan bahwa ada pengaruh latihan sirkuit training terhadap hasil lari sprint 60 meter pada peserta didik ekstrakulikuler SMP Negeri 21 Terpadu Pontianak, setelah dilakukan penghitungan hasil pengolahan data ternyata ada pengaruh latihan sirkuit training terhadap hasil lari sprint 60 meter pada peserta didik ekstrakulikuler SMP Negeri 21 Terpadu Pontianak, hal ini disebabkan karena beberapa hal yang terjadi antara lain : (1) Faktor kesungguhan sampel saat melakukan test akhir karena yang menilai adalah guru penjas sekalian mencari siswa yang punya kemampuan untuk di siapkan dalam perlombaan; dan (2) Penelitian dengan latihan circuit training sehingga siswa ekstrakulikuler dapat melakukan latihan lari sprint 60 meter dengan menyenangkan siswa dan siswa tertantang untuk mencoba dan terus mencoba lagi.

Didalam proses latihan lari sprint 60 meter dengan metode latihan sirkuit training yang digunakan berpengaruh terhadap proses latihan yang berlangsung. Beberapa post atau model latihan circuit training yaitu, push up, running drill hign knee bounce skips, sit up, split sguat jump, running drill bounding, sguat thrus, lari naik tangga, sprint 20 meter, dan sprint 80 meter. Berdasarkan hasil tersebut diartikan bahwa latihan circuit training menjadi salah satu latihan yang cukup efektif untuk meningkatkan kondisi fisik seorang atlet. Menurut Rahima Ayu Puri dalam Jurnal kedokteran dipenogoro tahun 2017 menjelaskan bahwa circuit training adalah suatu bentuk latihan fisik berinterfal, dimana didalamnya terdapa gabungan latihan kekuaan dan aeroik untuk melatih kekuatan fisik serta kelenturan tubuh. Hal tersebut dikarenakan 
dalam latihan circuit training mengandung latihan kekuatan, daya tahan, daya ledak, fleksibilitas, koordinasi, kecepatan, reaksi dan keseimbangan. Dengan latihan yang terus menerus dilakukan tersebut dapat memberikan beban tubuh yang akan terbiasa untuk menerima latihan. Sehingga kondisi fisik akan terlatih menjadi lebih baik. yang terpenting dalam latihan adalah intensitas latihan yang terus menerus dilakukan. Karena beberapa hari saja peserta didik tidak melakukan aktifitas maka akan mempengaruhi kondisi fisik. Menurut Sadoso Sumosardjuno (1998:8) juara tidak dilahirkan tetapi harus dibentuk dan diciptakan meskipun bakat merupakan faktor yang dominan. Bakat dapat diketahui dari faktor intern atlet yang merupakan pembawaan sejak lahir.

Latihan harus dilakukan terus menerus dengan beban yang meningkat dan terukur sehingga ada perubahan yang terjadi, latihan bisa disebut aktivitas untuk meningkatkan keterampilan atau bisa disebut kemahiran berolahraga dengan menggunakan berbagai peralatan sesuai dengan kebutuhan dan tujuan berolahraga. Oleh karena itu kelompok yang diberikan perlakuan dengan latihan circuit training terhadap hasil lari sprint 60 meter. Dengan demikian hipotesis yang menyatakan bahwa ada pengaruh metode latihan circuit training terhadap hasil lari sprint 60 meter peserta didik ekstrakulikuler SMP Negeri 21 Terpadu Pontianak. Latihan ini memberikan kegiatan latihan yang menarik dan menyenangkan bagi seorang atlet, sehingga dapat meningkatkan gairah dan motivasi untuk menguasai teknik yang telah diajarkan. Latihan adalah proses sistematis

\section{KESIMPULAN DAN SARAN \\ KESIMPULAN}

Berdasarkan data hasil penelitian yang telah didapatkan dan hasil penghitungan data, perhitungan nilai $t_{\text {test }}$ adalah 5,869 > nilai $t_{\text {tabel }}$ 1,729 sehingga hipotesis (Ha) diterima dan hipotesis nihil (Ho) ditolak. Artinya ada pengaruh metode latihan circuit training terhadap hasil lari sprint 60 meter pada peserta didik ekstrakulikuler SMP Negeri 21 Terpadu Pontianak, peningkatan rata-rata hasil lari sprint 60 meter pada peserta didik ekstrakulikuler atletik SMP Negeri 21 Terpadu Pontianak pada pretest adalah 9,609 sedangkan pada posttest adalah 9,335 (meningkat 0,274) jadi terdapat peningkatan sebesar $2,86 \%$.

\section{Saran}

Berdasarkan pembahasan kesimpulan yang sudah didapatkan maka saran yang paling tepat ada: (1) Perlunya pembinaan latihan lari sprint di gali secara mendasar dan menyeluruh agar latihan-latihan bisa diaplikasikan dengan baik dan sesuai kebutuhan atlet ; (2) Perlunya inovasi baru berupa media-media yang bisa mendorong untuk kualitas kinerja atlet berupa kebugaran, keterampilan dan kapasitas energi. Latihan adalah suatu program latihan fisik yang direncanakan untuk membantu mempelajari keterampilan memperbaiki kesegaran jasmani dan terutama untuk mempersiapkan atlet dalam suatu pertandingan penting dan suatu proses penyempurnakan kualitas atlet secara sadar untuk mencapai prestasi yang maksimal dengan diberi beban fisik dan mental secara teratur, terarah, bertahap, meningkat dan berulang-ulang waktunya (Atiq, 2018: 5-6). Melalui latihan dengan kondisi fisik peserta didik lebih berkembang.

Banyak kondisi yang terjadi dilapangan yang memiliki pengaruh terhadap peningkatan peserta didik, salah satunya adalah semangat mereka dalam mengikuti latihan, selain itu juga sikap disiplin mereka juga sangat memberikan dampak pada prestasi yang ada, proses keaktifan peserta didik dilapangan, antusias peserta didik dalam mengikuti kegiatan sangat memberikan dampak positif terhadap perkembangan peserta didik. Hal ini memberikan sumbangan yang besar dalam peningkatan yang ada. Berlandaskan pada keberhasilan latihan tersebut tentu saja dapat menjadi sebuah faktor pendorong dalam pencapaian tujuan latihan tersebut para peserta didik akan dapat memaksimalkan dirinya sendiri dalam peningkatan prestasi yang ada baik prestasi belajar atau prestasi olahraga disekolah maupun luar sekolah. Selain itu juga dengan motivasi yang ada tersebut dapat mengembangkan diri peserta didik baik itu pengembangan kognitif, afektif dan psikomotorik.

siswa dalam melakukan pembinaan cabor atletik sprint di SMP Negeri 21 Terpadu Pontianak.

\section{DAFTAR RUJUKAN}

Adang, S. (2009). Revitalisasi pengajaran dalam pendidikan jasmani. Bandung: FPOK UPI.

Arikunto. (2006). Prosedur Penelitian Satuan Pendekatan Praktek. Jogjakarta : Pustaka Pelajar Jogja Offset.

Atiq, A. (2018). Model Latihan Teknik Dasar Sepakbola Berbasis Bermain Untuk Atlet Pemula Usia 8-12 Tahun. Sidoarjo: Zifatama.

Burhan, N dkk. (2000). Statistika Terapan untuk Ilmu-Ilmu Sosial. Yogyakarta: Gadjah Mada University Press.

Eddy, P dkk. (2013). Dasar - Dasar Gerak Atletik. Yogyakarta : Alfamedia.

Hanief, Y N dkk. (2017). Stastika Pendidikan. Yogyakarta : Deepublish.

Kardjono. (2008). Modul Mata Kuliah Pembinaa Kondisi Fisik.

FPOK.Universitas Pendidikan Indonesia.

Khomsin. (2008). Atletik 2. Semarang : UNS. 
Juliantine, dkk. (2007). Teori Latihan. Bandung. Universitas Pendidikan Indonesia.

Soekarman. (1987). Dasar Olahraga untuk Pembina, Pelatih dan Atlet. Jakarta: Inti Indayu Press.

Sadoso, S. (1992). Kesehatan Olahraga. Pengetahuan praktis kesehatan dan olahraga. Jakarta : Pustaka Kartini.

Sugiyono. (2010). Metode Penelitian Pendidikan (Pendekatan Kuantitatif, Kualitatif Dan R\&D). Bandung: Alfabeta.
Sugiyono. (2011). Metode Penelitian Pendidikan (Pendekatan Kuantitatif, Kualitatif Dan $R \& D)$. Bandung: Alfabeta.

Sugiyono. (2016). Metode Penelitian Pendidikan (Pendekatan Kuantitatif, Kualitatif Dan R\&D). Bandung: Alfabeta.

Sutrisno, H. (2004). Metodologi Research 2. Andi Offset. Yogyakarta.

Tandiyo, R. (2009). Mengenal Pemain. Kementerian Negara Pemuda dan Olahraga Republik Indonesia. 